\title{
Stereotypies and suffering
}

\author{
G.J. Mason \\ Sub-department of Animal Behaviour, University of Cambridge, Madingley, UK
}

(Accepted 23 May 1991)

\begin{abstract}
Stereotypies often develop in environments that independent evidence shows cause poor welfare. Thus the development of stereotypies indicates that well-being has probably been poor, with the animal motivated to show a behaviour pattern that it could not perform normally or to completion. The continued performance of stereotypies may also indicate current suffering. However, an individual or population's degree of stereotypy does not necessarily correspond to the degree to which its well-being or welfare is impaired. This would require individual differences in stereotypy level to be the product of motivational differences and nothing else. In fact, they are also likely to be influenced by an animal's tendency to respond to the eliciting aspects of its environment with active behaviour rather than in a more inactive way. Stereotypy levels are also likely to be influenced by the general propensity of the individual to develop inflexible behavioural routines. Furthermore, as a stereotypy develops and becomes more habit-like it may be performed in circumstances where well-being is not at stake. Thus when comparing animals, lower levels of stereotypy do not necessarily reflect better well-being. Ceneral rules about the levels of stereotypy that are deemed "acceptable" from a welfare point of view are of limited use in reducing animal suffering unless they take take these factors into account. There is a great need for more research into the developmental processes responsible for stereotypies.
\end{abstract}

Key words: Animal welfare; Stereotypy; Suffering

\section{Introduction}

Stereotypies are repetitive, unvarying and apparently functionless behaviour patterns typical of animals in somc conditions of captivity (e.g. Fox 1965; Ödberg 1978; reviewed

Correspondence to: G.J. Mason, Sub-department of Animal Behaviour, University of Cambridge, Madingley CB3 8AA, UK. 
by Mason, 1991). They have long been thought a sign of a sub-optimal environment (e.g. Hediger 1950; Stolba et al. 1983, citing Brummer 1978; Ödberg 1987a), in which the animal's welfare is poor (e.g. Wiepkema 1983; Broom 1983; Luescher and Hurnik 1987). For most of these authors poor welfare is synonymous with suffering or poor well-being, and concerns mental states experienced by the animal as unpleasant (e.g. Duncan and Petherick 1989; Dawkins 1990; cf. Broom, in press a, b).

Stereotypies are thought a to be sign of poor well-being for three main reasons (reviewed by Mason, 1991): the type of environments in which they develop; the type of behaviour patterns from which they develop; and the type of factors that increase the performance of existing, established stereotypies.

Stereotypies often develop in situations of low stimulus input, physical restraint, and inescapable fear or frustration. These are situations that behavioural and physiological data indicale to be aversive and stressful. Indeed, a behavioural sign of aversion or internal conflict, such as an attempt to escape or a displacement activity, is sometimes the very source from which a stereotypy develops. Furthermore, once well established, stereotypies are often elicited on exposure to a stressor, or to barren conditions.

On these grounds, a stereotypy might be thought a reliable sign of poor well-being. Attempts have therefore been made to stipulate the levels that indicate a serious welfare problem, on the assumption that the more inadequate the environment, the more frequent or long-lasting will be the stereotypy (e.g. Fox 1984, pp. 189-191; Dawkins 1990). For example, Broom (1983) has suggested that stereotypies should be viewed with alarm if they take up more than $10 \%$ of an animal's time, while Wiepkema (1983) has proposed that welfare is unacceptable if they occur in more than $5 \%$ of a population. The question "At what level of abnormal behaviour is welfare poor?" continues to be asked today (e.g. Barnett and Hemsworth 1990; Dawkins 1990; Broom, in press a).

However, there are problems in deciding on cut-off criteria for the judging of welfare. These include the necessity of being able to measure the welfare criterion accurately (Mendl, in press); the influences of economics and public awareness upon what is considered acceptable; and the arbitrary nature of inflexibly quantititive dividing lines. In this paper, I discuss the specific problems with using levels of stereotypy to indicate levels of well-being.

\section{Some Problematic Examples}

Stereotypies are typically developed and performed in aversive situations, but there are exceptions to this generalisation. These show that there is no simple one-to-one correspondence between stereotypy and well-being.

\section{Stereotypy development}

Behaviour patterns that fit the definition of stereotypy sometimes arise in conditions for which there is no sign of aversion. For example, children may perform rhythmic movements, such as banging the head on the pillow, just before they fall asleep (Chamove, pers. comm.). Digit-sucking, considered a stereotypy by Levy (1944), for example, can sometimes be seen in the human foetus, in utero (Sroufe and Cooper 1988, p. 114). 
Nor are the behaviour patterns from which stereotypies develop always associated with stress or frustration. For example, they may be anticipatory, appetitive sequences, such as sham chewing in pigs Sus scrofa domestica (Rushen 1984) and pre-feeding excited-seeming locomotory behaviour in carnivores (e.g. de Jonge et al. 1986). The body-rocking and hand movements common in primates reared in barren conditions may be rooted in the similar movements of normal primates at stages of infancy (Berkson 1967; Thelen 1979). Territorial scent-marking may become a stereotypy, as it did in one pine marten Martes martes (Hediger 1950, p. 76).

Conversely, chronically sub-optimal conditions do not always give rise to stereotypies. For example, after prolonged and restrictive tethering, sows spend a good deal of their time inert (e.g. Broom 1986a). Similarly, aversive situations such as exposure to chronic electric shock are often associated with immobility rather than stereotypy (Robbins et al. 1990).

\section{Stereotypy performance}

The performance of a stereotypy can be triggered or enhanced by factors that are not aversive and hence have no significance for welfare (e.g. Kennes et al. 1988).

One such influence is social facilitation: the rate of development of stereotypies may be accelerated if an animal's neighbours show the behaviour (Palya and Zacny 1980; Kiley-Worthington 1983).

Once established, stereotypies may be elicited by states of generally raised activity or excitement (arousal: Einon and Sahakian 1979) that would not seem to involve negative emotion. For example, the body-rocking movements of chimpanzees Pan troglodytes reared in isolation are said to increase with "general arousal" (Berkson and Mason 1964). Stabled horses Equus caballus (Meyer-Holzapfel 1968) and intensively-housed pigs (Cronin 1985) often perform stereotypies just before they defaecate or urinate; and the pacing of a Cape hunting dog Lycaon pictus in a zoo would increase when its keeper approached with food (Fentress 1976). The stereotypies of caged voles Clethrionomys glareolus covary with normal behaviour patterns, in a diurnal polyphasic rhythmn of general activity (Ödberg 1986); and the stereotypies of caged foxes are performed, not before feeding as in many other captive carnivores, but at night, when these nocturnal animals are most active (de Jonge, pers. comm.).

Established stereotypies are also commonly performed when little is happening in the environment, and arousal is probably low. This is true, for example, of flying to and fro in caged birds (Hinde 1962), finger-sucking and other stereotypies in children (Levy 1944; Berkson 1967) and rocking in laboratory-caged chimpanzees (Berkson 1967). Some captive mink Mustela vison perform stereotypies in the quiet, calm hours after the delivery of food (de Jonge et al. 1986), and at a more gentle rate than the stereotypy they perform immediately pre-feeding (Mason, pers. obs.). Although such stereotypies have been interpreted as responses to "boredom" (e.g. Berkson 1967; Barnett and Hemsworth 1990), i.e. to stimulation or arousal falling below optimal limits (e.g. Wemelsfelder 1990), there seems to be no empirical evidence that the performance of stereotypy at such times really does reflect an increase in how aversive the animal is currently finding its environment.

In addition, a stereotypy may become incorporated into the normal behaviour of an animal, and to such an extent that its performance is often completely independent of aversive aspects of the environment. For example, the "head-swing" developed by one 
stereotypically pacing dingo Canis dingo, came to be shown whenever the animals made any turning movement, regardless of the circumstances (Fox 1971).

Thus increased stereotypy does not necessarily reflect a reduction in well-being. Neither does decreased stereotypy always indicate an improvement. For example, stereotypies may be inhibited by stressors. Immobilisation stress depresses the development of drug-induced stereotypy in a strain of mouse (Cabib et al. 1985; see also Sahakian and Robbins 1975; Robbins and Sahakian 1981), and intense aversive stimuli, such as loud noises, can interrupt stereotypy performance (e.g. Fentress 1976; 1977; Robbins and Sahakian 1981). The effects can be quite longlasting. For example, the stereotypies of captive mink caught up and moved to a new cage, did not return to their original levels for 5 or 6 days (Heller and Jeppesen 1990). Hormonal changes, with no concommittant change in welfare, may also reduce stereotypy. Stereotypy in tethered sows, for example, drops after the 80th day of pregnancy (Cronin and Wiepkema 1984).

\section{Environmental enrichment}

Changes can be made to animal's environment that would appear to improve it in terms of welfare, but which do not decrease stereotypy levels. For example, voles reared in a barren cage develop more stereotypy then those reared in a large cage with a complex environment (Ödberg 1987b). The latter would seem an improvement; yet a vole transferred from the impoverished to an enriched cage may show no decrease in its stereotypy (Cooper and Ödberg 1991). Similarly, a capuchin monkey (Cebus) retained its pace-and-twist stereotypy, unchanged, when moved from a small to a new and larger cage (Morris 1964). There are many similar cases.

\section{Correlates of stereotypy}

Individuals showing stereotypy often give no other sign of currently finding their environment adverse or aversive. They may appear emotionally neutral, such as the "turning dingo" mentioned above, or even to have enhanced well-being. For example, hens that develop pacing when frustrated, stop alarm-calling once the pacing reaches a high level (Duncan \& Wood-Gush 1972), and amongst humans, stereotypies such as the strange hand movements of schizophrenics and amphetamine-addicts are reported pleasurable (Fox 1971; Rylander 1971, cited by Robbins and Sahakian 1981).

\section{Conclusion}

These examples illustrate that stereotypies are not entirely reliable as indicators of current emotional state or past environmental inadequacy. They cast doubt on assumptions that the greater the degree of stereotypy, the worse an animal's welfare. The key to understanding the complex relationship between stereotypies and suffering lies in examining the processes involved in the development and performance of stereotypies. These I discuss in the next section. 


\section{Processes Involved in Development and Performance of Stereotypies}

Three important factors complicate the link between stereotypies and well-being: (1) the properties of the behaviour control systems responsible for their development; (2) the change in the specificity of their causal factors with age; and (3) the consequences of performing them.

\section{Mechanisms behind stereotypy}

The development of a stereotypy or indeed any stereotyped, unvarying behaviour pattern often appears to depend on a behaviour pattern being performed often (e.g. Lashley 1921; Miller et al. 1960, pp. 81-93; Meyer-Holzapfel 1968; Fentress 1976), and there being little in the environment to cause variation or termination of the movements (Hediger 1950; Morris 1964; Morris 1966; Dantzer 1986; Duncan and Hughes 1988). Eventually the repeated behaviour becomes less and less dependent on environmental factors for the control of its organization (e.g. Fentress 1977; see also Martiniuk 1976, on "closed"-type motor skills), perhaps because of "sensitization" of the neuronal pathways involved (e.g. Stolba et al. 1983; Dantzer 1986). The animal acts as though stuck in a behavioural rut.

Hence stereotypy development requires that an animal: (a) responds to the environment by showing active behaviour; (b) repeats this behaviour; and (c) becomes very unvarying in its movements.

There is a growing body of evidence that animals differ in all three of these aspects of behaviour. Such variation between animals could be a source of differences in their stereotypies.

\section{Responding to captive environment}

Life in captivity is very different from that for which natural selection has equipped an animal. It will have to expend far less time and energy on meeting its physiological needs, patrolling its territory, finding a mate, and so on. It may also be faced with aversive situations over which it has no control, such as being physically restrained, or disturbed by humans. In these circumstances, the animal may respond by showing active behaviour or by becoming relatively inert. What it does may depend on its species, its sex, its own individual tendencies, and the specific situation to which it is exposed.

For example, when provided with food some species, such as lions Panthera leo, become very inactive, whilst others, such as mongooses (Herpestinae), continue to perform appetitive or exploratory behaviour as though it still had a function (Morris 1964; see reviews by Ödberg 1987a and Mason, 1991). Similarly, when faced with a strongly aversive stimulus, some species will show active avoidance behaviour, whilst others will freeze (Bolles 1970; Archer 1979).

Behavioural responses may be influenced by sex; Archer (1979) reviews evidence that female rats are more prone to escape actively when shocked, males to become immobile.

Responses may also differ at the individual level. For example, individuals may differ in their thresholds for the elicitation of a response, or in the magnitude of that response. Individual differences may be qualitative as well as quantitative. For example, some rats Rattus norvegicus (Katzev and Mills 1974; Dantzer et al. 1988) and house mice Mus musculus (Benus et al. 1990) freeze when given electric shocks, while others attempt to 
flee. The same is true of rats (Dantzer et al. 1988) and tree shrews Tupaia belangeri (von Holst 1986, 1989) faced with an aggressive conspecific, and dogs presented with a novel object (Goddard and Beilharz 1986). Benus and coworkers coined the terms "active" and "passive" for these two extreme styles of reacting to adversity (e.g. Koolhaas 1989).

The tendency to show active behaviour, rather than freezing or behaving as if apathetic is likely to be an important determinant of an animal's tendency to stereotypy. Indeed Ödberg $(1986 ; 1987 b)$ has found that voles with the most stereotypy were also the most generally active, and tended to flee, rather than freeze, when startled by a strange noise.

The type of behavioural response also depends on the nature of the stressor. Chronic cold, for example, is generally associated with relative immobility (Robbins et al. 1990), as are distant or uncertain threats of predation, and low-level or diffuse (as opposed to intense or localised) electric shocks (Archer 1979). This could explain why aversive situations do not always give rise to stereotypy (see Robbins et al. 1990).

\section{Sustaining a response}

Whether a behavioural response is repeated in a sustained enough manner for a stereotypy to develop may also be influenced by factors not immediately related to welfare. One could imagine a response waning more rapidly in an animal that is a quick learner, if the expected consequences were not forthcoming; or in an animal that is soon exhausted (e.g. Hinde 1970, p. 140), or readily distracted into performing other behaviour patterns.

\section{Developing a routine}

As early as 1939, Holzapfel (cited by Hediger 1950) pointed out that the "tendency to habit formation" played an important role in the development of stereotypies. Dantzer (1989) also emphasized the likely importance of a general "inability to shift behavioural programmes".

Individuals seem to differ in their tendency to develop habits or routines, i.e. patterns of behaviour that are relatively unvarying and resistant to change (Miller et al. 1960; Wiepkema 1987). These differences appear to have a neurophysiological basis (reviewed by Dantzer et al. 1988).

For example, in their studies of the house mouse, Benus et al. $(1987 ; 1988 ; 1990$; Koolhaas 1989) found considerable individual variation in the ability to adapt current behaviour rapidly to a change in the physical or social environment. The most flexible animals did not learn the original tasks any more readily (Benus et al. 1990), but they tended not to build routines after repeating the same behaviour several times, instead staying exploratory and alert to stimuli in the environment. The same appears true among rats (Benus et al. 1987; Dantzer 1989). Rats have also been found to differ in the length of time for which they will persist with a learned avoidance response during extinction (Owen 1963, cited by Mills and Katzev 1974).

Factors that decrease behavioural flexibility or responsiveness to environmental stimuli include learning ability (Martiniuk 1976, pp. 144 and 150; Fagen 1982; Benus et al. 1990); neuronal systems that are readily sensitized (Dantzer 1986; 1989); a very low or very high inherent level of arousal (e.g. Martiniuk 1976, p. 44); endogenous opioids (Dantzer 1986); ACTH (e.g. de Wied et al. 1972; reviewed by McEwen et al. 1986); corticosteroids (which increase retention of an avoidance response, during extinction; reviwed by McEwen et al. 1986); testosterone (Andrew 1976; 1989; van Oortmerssen et al. 1985); and other hormones. For example, Stolba et al. (1983) have suggested altered 
levels of reproductive hormones as the reason why the repeated, chronically thwarted attempts of pregnant sows to prepare a nest do not become fixated. Individual differences may be genetic (e.g. Benus et al. 1990), due to differences in experience, or due to an interaction between the two.

Experiential factors that increase the tendency to get locked into an unvarying behaviour pattern include physically and socially impoverished rearing conditions (Luchins and Forgus 1955; Morgan 1973; reviewed by Fagen 1982; Jones et al. 1989). Even within a social group, the flexibility of behaviour may be influenced by differential experience. The acquisition of new behavioural traits in response to novelty in the environment is more rapid by lower than the top-ranking individual jackdaws Corvus monedula (Katzir 1982) and Japanese macaques Macaca fuscata (e.g. Menzel 1966, cited by Katzir 1982).

\section{Summary}

As the examples above illustrate, animals differ in their tendency to show active behaviour rather than relative inactivity, and in how prone they are, generally, to get locked into routines. Such differences may influence stereotypy levels as much as do motivational factors, i.e. factors that are significant for welfare. Furthermore, if an active and sustained motor response, rather than aversiveness per se, is a prerequisite for the development of stereotypy, this could explain why the circumstances that give rise to stereotypies are not always sub-optimal and why, conversely, aversive environments do not always result in stereotypies. It could also explain why the well-being of stereotypic individuals does not always appear poorer than non-stereotypic ones. ${ }^{1}$

\section{Nature of established stereotypies}

Once a behaviour pattern has become a stereotypy, with time and repetition it can change further. Long-established stereotypies differ from developing ones in a number of ways (reviewed by Mason, 1991): ways that further loosen the ties between current well-being and performance of the behaviour.

Older stereotypies, for example, become more resistant to change, and hence more difficult to abolish by enriching the environment.

Established stereotypies are also elicited by a broad range of events, no longer by the original causal stimulus alone (e.g. Fentress 1976). This uncoupling of performance from the original eliciting factor is known as emancipation (see Groothuis 1989). Such stereotypies may be performed at times when there is little competition from other, higher priority, behavioural systems (e.g. Hinde 1962; 1970; Duncan and Wood-Gush 1974, interpreting the data of Keiper 1970), and in drowsy animals who perhaps have a reduced capacity to process information (Fentress 1976; see also Martiniuk 1976, pp. 40-44).

The reduced specificity of established stereotypies' eliciting factors also leads to their being performed when general arousal increases (Fentress 1973; 1976; Ridley and Baker 1982). Fentress (1976) demonstrated this in squirrel monkeys Saimiri sciureus, by eliciting

1 Differing tendencies to become habit-like and ritualized may also explain why some behaviour patterns seem more prone than others to develop into stereotypies-perhaps analogously to the way that typists find that copy-typing becomes automatic much more readily than does audio-typing ( $E$. Paul, pers. comm.). For example, tracing fixed pathways may be species-typical of, say, the rat (e.g. Daly 1977). 
their stereotypies through electrical stimulation of the mesencephalic reticular system. He suggested that for established stereotyped movements, "various disturbances [have] relatively diffuse excitatory effects". Thus when an arousing event such as a loud noise elicits an established stereotypy (e.g. Berkson and Mason 1964), the behaviour may be an epiphenomenon of raised arousal, rather than a specific response to aversion per se.

The properties of established, "emancipated" stereotypies help explain why stereotypies can be modulated by factors with no welfare significance (such as urination); why animals performing stereotypy do not always appear distressed; and why environmental improvement can sometimes leave a stereotypy unchanged.

\section{Stereotypies' consequences}

It has been suggested that stereotypies reduce the negative emotion that would otherwise be associated with the eliciting environment, and that they may even increase positive emotions such as pleasure or satisfaction. Such ideas have arisen because of evidence associating stereotypies with reduced behavioural and physiological signs of stress or distress (reviewed by Ödberg 1987a and Mason 1991).

A number of hypotheses attempt to explain this. For example, a stereotypy may have reinforcing, hedonistic, properties through being an adequate outlet for the expression of behaviour that the animal cannot perform normally, such as territory-patrolling; or through modifying arousal in some way (reviewed by Mason 1991).

There are two main problems with the idea that stereotypy has beneficial consequences. First, the supporting evidence is largely correlational. For example, Cronin's hypothesis (1985) that stereotypy is associated with a release of opioids is an intriguing idea, and often quoted (e.g. Hughes and Duncan 1988; Barnett and Hemsworth 1990; Dawkins 1990; Fraser and Broom 1990). However, his data showed only that stereotypy was abolished by administration of an opioid receptor antagonist. Abolition was immediate, rather than preceded by the temporary increase in behaviour one might expect in an animal trying to compensate for the block by boosting opioid production (as in self-mutilating humans, Richardson and Zaleski 1986; and rats which self-inject with morphine, Dantzer 1990b) ${ }^{1}$. This might suggest that the stereotypy was not in fact the cause of opioid output. Furthermore, nor is this hypothesis supported by any signs of stereotypy-induced analgesia (Rushen et al. 1990).

A second problem is that stereotypies differ so much, for example, in source behaviour and with stage of development (reviewed by Mason, 1991), that one stereotypy may improve an animal's well-being, while another, or the same stereotypy in a different context, may not.

Overall, however, some stereotypies may be coping responses, reducing the negative emotions associated with the eliciting environment, and improving well-being. This could explain why stereotyping animals do not always appear stressed, and why improving an animal's conditions sometimes has no effect on stereotypy levels.

1 Though see Olds and Milner (1954), for how electrical self-stimulation of the brain is abolished immediately in the extinction condition. 


\section{Conclusion}

Like a scar, a stereotypy tells us something about past events. It suggests that previously, a behaviour pattern has been repeatedly elicited, and probably in an environment that has demanded little variation in performance. In captivity, sustained repetition may occur because the behaviour cannot reach a satisfactory, consummatory conclusion, and in barren conditions the behaviour is unlikely to be interupted by higher priority behaviour patterns. Thus stereotypies should warn us that the animal has probably been in an unchanging and frustrating environment, and that its welfare has probably been unsatisfactory. Much evidence does indeed link the development of stereotypies with specific sub-optimal environments. The development of a stereotypy in an individual is therefore the sign of an animal that has probably been suffering, and whose well-being may be poor still.

Quantitative and qualitative details of the stereotypy might be assumed to provide more precise information about an animal's well-being. The amount or frequency of a stereotypy could depend solely on how intense the animal perceived the eliciting stimuli to be, i.e. on the strength of its motivation to perform normal behaviour (Rushen 1984; Ödberg 1987a; Dawkins 1990; see also Hinde 1970, pp. 139-147). If this were so, it would be fair to assume that individual differences in stereotypy reflect the aversiveness of the situation, and hence negative emotion (e.g. McFarland 1989, p. 48; Dawkins 1990). However, there are empirical and theoretical grounds for doubting the story to be this simple.

For one thing, the possibility that stereotypy has consequences complicates the picture. Its performance could reduce the strength of the underlying motivation (e.g. Ödberg 1987a). Individual differences might still reflect differences in past suffering and, according to one definition (Broom 1986b; in press a, b), current welfare, but the animals would not differ in current well-being; their reduced motivation would reduce the suffering felt in an environment that did not allow the normal expression of the behaviour (e.g. Nicol and Guilford 1991).

Furthermore, there are other factors that could equally explain differences between animals in their stereotypy levels. An individual's degree of stereotypy is likely to be influenced by properties of the control systems responsible for the behaviour: i.e. by the readiness with which active behaviour is elicited by the circumstances in question; the tendency of the response to become unvarying; the ease with which the established stereotypy is elicited in a range of other circumstances; and the resistance of that stereotypy to modulation by changes in the environment. Differing behavioural responses could represent different styles of reacting to the same underlying motivation (e.g. Ödberg 1987a). Hence one should not assume that all aspects of a stereotypy can be explained or interpreted in terms of welfare. For example, the well-being of animals with little, or easy-to-interrupt, stereotypy is not necessarily better than that of animals with a greater degree of the behaviour (cf Broom, in press a, who asserts "a great deal of stereotypy indicates poorer welfare than an occasional stereotypic action"). Rules that stipulate "acceptable" or "unacceptable" levels of stereotypy will not be useful in improving animal welfare unless they take into account the full range of factors that may influerice an animal's degree of stereotypy. This highlights the need for more research into the processes responsible for stereotypies. 


\section{Acknowledgements}

With grateful thanks to Pat Bateson, Don Broom, Robert Dantzer, Mike Mendl, Frank Ödberg and Piet Wiepkema for comments and discussion.

\section{References}

Andrew, R.J., 1976. Attentional processes and animal behaviour. In: P. P.G. Bateson and R.A. Hinde (Editors), Growing Points in Ethology. Cambridge University Press, pp. 95-134.

Andrew, R.J., 1989. Short latency effects of androgen and oestrogens on attention and motor plans. Paper given at the International Ethological Congress, Utrecht.

Archer, J., 1979. Behavioural aspects of fear. In: W. Sluckin (Editor), Fear in Animals and Man. Van Nostrand Reinhold, New York, pp. 56-85.

Barnett, J.L. and Hemsworth, P.H., 1990. The validity of physiological and behavioural measures of animal welfare. Appl. Anim. Behav. Sci. 25: 177-187.

Benus, R.F., Koolhaas, J.M., and Oortmerssen, G.A. van., 1987. Individual differences in behavioural reaction to a changing environment in mice and rats. Behaviour 100: 105-122.

Benus, R.F., Koolhaas, J.M. and van Oortmerssen, G.A. , 1988. Aggression and adaptation to the light-dark cycle: role of intrinsic and extrinsic control. Physiol. Behav. 43: 131-137.

Benus, R.F., Daas, S. den, Koolhaas, J.M. and van Oortmerssen, G.A., 1990. Rouline infurmation and flexibility in the social and non-social behaviour of aggressive and non-aggressive mice. Behaviour 112: 176-193.

Berkson, G., 1967. Abnormal stereotyped motor acts. In: J. Zubin and H.F. Hunt (Editors), Comparative Psychopathology - Animal and Human. Grune and Stratton, New York, pp. 76-94.

Berkson, G. and Mason, W.A., 1964. Stereotyped behaviors of chimpanzees: relation to general arousal and alternative activities. Percept. Motor Skills 19: 635-652.

Bolles, R.C., 1970. Species-specific defense reactions and avoidance learning. Psych. Rev. 77: 32-48.

Broom, D.M., 1983 Stereotypies as animal welfare indicators. In: D. Schmidt (Editor), Indicators relevant to Farm Animal Welfare. Martinus Nijhoff, The Hague, pp 81-87.

Broom, D.M., 1986a. Responsiveness of stall-housed sows. Abstract, Appl. Anim. Behav. Sci. 15: 186.

Broom, D.M., 1986b. Indicators of poor welfare. Brit. Vet. I. 142:524-525.

Broom, D.M., in press a, f. Anim. Sci. Animal welfare: concepts and measurement.

Broom, D.M., in press b, J. agric. ethics. A usable definition of animal welfare.

Cabib, S., Puglisi-Allegra, S. and Oliverio, A., 1985. A genetic analysis of stereotypy in the mouse. Behav. Neur. Biol. 44: 239-248.

Cooper, J. and Ödberg, F., 1991. The emancipation of stereotypies with age. In: Appleby, M.C., Howell, R.I., Petherick, S.C. and Rutter, S.M. (Editors), Applied Animal Behaviour: Past, Present and Future. UFAW, Potter's Bar, p. 112.

Cronin, G., 1985. The development and significance of abnormal stereotyped behaviours in tethered sows. PhD thesis, Agricultural University of Wageningen, The Netherlands.

Cronin, G.M. and Wiepkema, P.R., 1984. An analysis of stereotyped behaviour in tethered sows. Ann. Rech. Vet. 15: 263-270. Martinus Nijhoff, The Hague.

Daly, M. 1977. Early stimulation of rodents: a critical review of present interpretations. Br. J. Psychol. 64: $435-460$.

Dantzer, R., 1986. Behavioral, physiological, and functional aspects of stereotyped behavior: a review and are-interpretation. \}. Anim. Sci. 62: 1776-1786.

Dantzer, R, 1989. Neuroendocrine correlates of control and coping. In: A. Steptoe and A. Appels (Editors), Stress, Personal Control and Health. Wiley, Chichester, pp. 277-294. 
Dantzer, R., 1990a. Animal suffering: the practical way forward. Br. Behav. Sci. 13: 17-18.

Dantzer, K., 1990b. Behavioural, neuroendocrine and neurobiological aspects of stereotypies. Paper given at Stress and Abnormal Behaviour Workshop, Elsinor, Denmark, Sept. 1990.

Dantzer, R., Terlouw, C., Tazi, A., Koolhaas, J.M., Bohus, B., Koob, G.F. and le Moal, M., 1988. The propensity for schedule-induced polydipsia is related to differences in conditioned avoidance behaviour and in defense reactions in a defeat test. Physiol. Behav. 43: 269-273.

Duncan, I.J.H. and Petherick, J.C., (1989). Cognition: the implications for animal welfare. Abstract, Appl. Anim. Behav. Sci. 24: 81.

Duncan, 1.J.H. and Wood-Gush, D.G.M., 1972. Thwarting of feeding behaviour in the domestic fowl. Anim. Behav. 20: 444-451.

Duncan, I.J.H. and Wood-Gush, D.G.M., 1974. The effects of a rauwolfia tranquilizer on stereotyped movements in frustrated domestic fowl. Appl. Anim. Behav. Ethol. 1: 67-76.

Einon, D.F. and Sahakian, B.J., 1979. Environmentally-induced differences in susceptibility of rats to C.N.S. stimulants and C.N.S. depressants: evidence against a unitary explanation. Psychopharmacology 61: 299-307.

Fagen, R., 1982. Evolutionary issues in the development of behavioral flexibility. In: P.P.G. Bateson and P.H. Klopfer (Editors), Perspectives in Ethology 5: Ontogeny. Plenum Press, New York, pp. $365-384$.

Fentress, J.C., 1973. Specific and non-specific factors in the causation of behavior. In: P.P.G. Bateson and P.H. Klopfer (Editors), Perspectives in Ethology. Plenum Press, New York, pp. 155-224.

Fentress, J.C., 1976. Dynamic boundaries of patterned behaviour: interaction and self-organisation. In: P.P.G. Bateson and R.A. Hinde (Editors), Growing Points in Ethology. Cambridge University Press, Cambridge, pp. 135-167.

Fentress, J.C., 1977. The tonic hypothesis and the patterning of behavior. Ann. NY. Acad. Sci. 290: $370-395$.

Fox, M.W., 1965. Environmental factors influencing stereotyped and allelomimetic behaviour in animals. Lab. Anim. Care 15: 363-370.

Fox, M.W., 1971. Psychopathology in man and lower animals. J. Am. Vet. Med. Assoc. 159: 66-77.

Fox, M.W., 1984. Farm animals: husbandry, behavior and veterinary practice. University Park Press, Baltimore MD.

Fraser, A.F. and Broom, D.M., 1990. Farm animal behaviour and welfare. Balliere-Tindall, London. Goddard, M.E. and Beilharz, R.G., 1986. Early predictions of adult behaviour in potential guide dogs. Appl. Anim. Behav. Sci. 15: 247-260.

Groothuis, T., 1989. On the ontogeny of display behaviour in the black-headed gull II: Causal links between the development of aggression, fear and display behaviour: emancipation re-considered. Behaviour 110: 161-204.

Hediger, H., 1950. Wild animals in captivity. Butterworths Scientific Publications, London.

Heller, K.E. and Jeppesen, L.L., 1990. Stereotypies in ranch mink. Paper given at Stress and Abnormal Behaviour Workshop, Elsinor, Denmark, Sept. 1990.

Hinde, R.A., 1962. The relevance of animal studies to human neurotic disorders. In: D. Richter, J.M. Tanner, Lord Taylor and O.L. Zangwill (Editors), Aspects of Psychiatric Research. Oxford University Press, pp. 240-261.

Hinde, R.A. 1970. Animal Behaviour (2nd edition). Mc-Graw Hill, New York.

von Holst, D., 1986. Vegetative and somatic components of tree shrews' behaviour. J. Autonomic Nerv. Syst. Suppl: 657.

von Holst, D., 1989. Positive and negative consequences of social behavior on reproduction and health in tree shrews. Paper given at the International Ethological Congress, Utrecht.

Hughes, B.O. and Duncan, I.J.H., 1988. The notion of ethological "need", models of motivation and animal welfare. Anim. Behav. 36: 1696-1707.

Jones, G.H., Robbins, T.W. and Marsden, C.A., 1989. Isolation-rearing retards the acquisition of schedule-induced polydipsia in rats. Physiol. Behav. 45: 71-77.

de Jonge, G., Carlstead, K., and Wiepkema, P.R., 1986 The Welfare of Ranch Mink. (Transl. from Dutch.) COVP issue no. 08, Het Spelderholt, Beekbergen, The Netherlands. 
Katzev, R.D. and Mills, S.K., 1974. Strain differences in avoidance conditioning as a function of the classical CS - US contingency. J. Comp. Physiol. Psychol. 87: 661-671.

Katzir, G., 1982. Relationship between social structure and response to novelty in captive jackdaws, Corvus monedula. I: Response to a novel space. Behaviour 81: 231-259.

Kennes, D., Odberg, F.O., Bouquet, Y. and de Rycke, PH., 1988. Changes in naloxone and haliperidol effects during the development of captivity-induced jumping stereotypy in bank voles. Eur. J. Pharmacol. 153: 19-24.

Kiley-Worthington, M., 1983. Stereotypes in horses. Equine Practice 5: 34-40.

Koolhaas, J.M., 1989. Aggression and coping: Individual differences in disease susceptibility. Paper given at the International thological Congress, Utrecht.

Kravitz, H., Rosenthal, V., Teplitz, Z., Murphy, J.B., and Lesser, R.E., 1960. A study of head-banging in infants and children. Dis. Nerv. Syst. 21: 203-208.

Lashlcy, K.S., 1921. Studies of cerebral function in learning 11: the effects of long continued practice upon cerebral localization. J. Comp. Psychol. 1: 453-468.

Levy, D.M., 1944 On the problem of movement restraint. Am. J. Orthopsychiat. 14: 644-677.

Luchins, A.S. and Forgus, R.H. 1955. The effect of differential post-weaning environment on the rigidity of an animal's behavior. J. Cen: Psychol. 86: 51-58.

Luescher, U.A. and Hurnik, J F., 1987. Contribution to a concept of behavioral abnormality in farm animals under confinement. In: Fox, M.W. and Mickley, L.D. (Editors), Adv. Anim. Welf. Sci. 1986-1987, Martinus Nijhoff, The Hague, pp. 67-76.

Martiniuk, R.G. 1976. Information Processing in Motor Skills. Holt, Rinehart and Winston, New York. Mason, G.J. 1991. Stereotypies: a Critical Review. Anim. Behav. 41: 1015-1037.

McEwen, B.S., Kloet, E.R. de, and Rostene, W. 1986. Adrenal steroid receptors and actions in the nervous system. Physiol. Rev. 66,1121-1188.

McFarland, D.J., 1989. Problems of Animal Behaviour. Longman Scientific and Technical, Harlow, Essex.

Mendl, M. (in press, Appl. Anim. Behav. Sci.). Some problems with the concept of a cut-off point for determining when an animal's welfare is at risk.

Meyer-Holzapfel, M., 1968. Abnormal behaviour in zoo animals. In: M.W. Fox (Editor), Abnormal Behavior in Animals. Saunders, London, pp 476-503.

Miller, G.A. , Galneter, E. and Pribram, K.H., 1960. Plans and structure of behavior. Holt, Rinehart and Winston, New York.

Mills, S.K. and Katzev, R.D., 1974. Differences in strains of rats during extinction of shuttle box avoidance responding. J. Comp. Physiol. Psychol. 87: 672-680.

Mittleman, G. Jones, G.H. and Robbins, T.W., 1988. The relationship between schedule-induced polydipsia and pituitary-adrenal activity: pharmacological and behavioural manipulations. Behav. Br. Res. 28: 315-324.

Morgan, M.J., 1973. Effects of past weaning environment on learning in the rat. Anim. Behav. 21: $429-442$

Murris, D., 1964. The response of animals to a restricted enviromment. Symp. Zool. Soc. London 13: 99-118.

Morris, D., 1966. The rigidification of behaviour. Phil. Trans. R. Soc. London B 251: 327-330.

Nicol, C... and Guilford, T. 1991. Exploratory activity as a measure of motivation in deprived hens. Anim. Behav. 41: 333-341.

Ödberg, F., 1978. Abnormal behaviours (stereotypies). In: Garsi (Editorial), Proceedings of the 1st World Congress on Ethology applied to Zootechnics. Industrias Graficas, Madrid, 475-480.

Ödberg, F., 1986. The jumping stereotypy in the bank vole (Clethrionomys glareolus) Biol. Behav. 11: 130-143

Ödberg, F., 1987a. Behavioural responses to stress in farm animals. In: P.W.M. van Adrichem and P.R. Wiepkema (Editors), The Biology of Stress in Farm Animals: an integrative Approach. Martinus Nijhoff, Dordrecht, pp 135-149.

Ödberg, F., 1987b. The influence of cage size and environmental enrichment on the development of stereotypies in bank voles (Clethrionomys glareolus) Behav. Proc. 14: 155-173. 
Olds, J. and Milner, P. 1954. Positive reinforcement produced by electrical stimulation of septal area and other regions of the rat brain. J. comp. physiol. Psychol. 47: 419-427.

Oortmerssen, G.A. van, Benus, I. and Dijk, D.J., 1985. Studies in wild house mice: genotype-environment interactions for attack latency. Neth. J. Zool. 35: 155-169.

Palya, W.L. and Zacny, J.P., 1980. Stereotyped adjunctive pecking by caged pigeons. Anim. Learn. Behav. 8: 293-303.

Ridley R.M. and Baker H.F., 1982. Sterentypy in monkeys and humans. Psychol. Med. 12: 61-72.

Robbins, T.W. and Sahakian, B.J., 1981. Behavioural and neurochemical determinants of drug-induced stereotypy. In: F. Clifford Rose (Editor), Metabolic Disorders of the Nervous System Pitman, London, pp. 244-291.

Robbins, T.W., Mittleman, G., O'Brien, J. and Winn, P., 1990. The neurobiological significance of stereotypy induced by stimulant drugs. In: S.J. Cooper and C.T. Dourish (Editors), The Neurobiology of Stereotyped Behaviour. Clarendon, Oxford, pp. 25-63.

Rushen, J., 1984. Stereotyped behaviour, adjunctive drinking and the feeding periods of tethered So,ws. Anim. Behav. 32: 1059-1067.

Rushen, J., Passillé, A.M. de and Schouten, W., 1990 Stereotyped behaviour, endogenous opioids and post-feeding hypoalgesia in pigs. Physiol. Behav. 48: 91-96.

Sahakian, B.J. and Robbins, T.W., 1975. The effects of test environment and rearing condition on amphetamine-induced stereotypy in the guinea-pig. Psychopharmacologia 45: 115-117.

Sroufe, L.A. and Cooper, R.G. (1988). Child Development - its nature and course. Alfred A. Knopf, New York.

Stolba, A., Baker, N., and Wood-Cush, D.G.M., 1983. The characterisation of stereotyped behaviour in stalled sows by informational redundancy. Behav. 87: 157-181.

Thelen, E., 1979. Rhythmical sterentypies in normal human infants Anim. Behav. 27: 699-715.

Wemelsfelder, F. 1990. Boredom and laboratory animal welfare. In: B.E. Rollin (Editor), The Experimental Animal in Biomedical Research. CRC Press, Boca Raton, Florida, pp. 243-272.

de Wied, D., van Delft, A.M.L., Gispen, W.H., Weijnen, J.A.W.M., and van Wimersma Greidanus, T.B., 1972. The role of pituitary-adrenal hormones in active avoidance conditioning. In: S Levine (Editor), Hormones and Behavior. Academic Press, New York, pp. 136-171.

Wiepkema, P.R., 1983. On the significance of ethological criteria for the assessment of animal welfare. In: D. Schmidt (Editor), Indicators relevant to Farm Animal Welfare. Martinus Nijhoff, The Hague, pp. 71-79.

Wiepkema, P.R., 1987. Behavioural aspects of stress. In: P.W.M. van Adrichem and P.R. Wiepkema (Editors), The Biology of Stress in Farm Animals: an Integrated Approach. Martinus Nijhoff, Dordrecht, pp. 113-134. 